\title{
BIOCLIMATIC ADAPTATION OF TYPICAL HOUSES IN KAMPONG'S SURABAYA
}

Failasuf Herman Hendra*, Antariksa, Agung Murti Nugroho, Amin Setyo Leksono

*) Department of Architecture, Institut Teknologi Adhi Tama Surabaya e-mail: failasuf_herman@yahoo.com

\begin{abstract}
The ancient house architecture in Kampong's Surabaya is one of the folk architecture creations in urban areas that grow and follow dynamics of urban development. In some areas in this city, this architecture is still sustainable for residents' living space, especially for lower and middle class. This sustainable happens because of building adaptation and occupant's adaptation. Bioclimatic adaptation can be one of the comprehensive design approaches which considers the relationship between architecture, climate, biology, technology, in order to obtain comfort and energy efficiency. Therefore, the kampong has a high adaptability to development of the city, so that, it can adjust to future conditions efficiently. Cultures living in kampong require an appropriate strategy in associating with various limitations. However, limitation does not make a typical house in kampong uncomfortable and unliveable. It seems that typical ancient house in Surabaya City is dominantly influenced by architectural traditions of Javanese, Colonial, and Modern building. The present study is designed to describe the form and performance of ancient houses in context with bioclimatic adaptation and also the occupant spatial interactions with the building. The data collected from observation, measurement, and questionnaire that taken from several alley of Kampong Peneleh, Surabaya. Then the data was analysing to explain the performance and interaction between the building and its occupant that creates typical architecture houses and its transformation. Result of the study showed that bioclimatic adaptation as a design strategy allowed unique form architecture, climate responsive and environmentally friendly. Facade technique and building envelops, eco-friendly building materials, vegetation, water elements and saving energy were appropriate technologies to apply.
\end{abstract}

Keywords: bioclimatic adaptation, typical, ancient house, Kampong's Surabaya

\section{INTRODUCTION}

Kampong is a residential area which the concentration of most urban population in Indonesia with its dynamics social, economic and environmental. The characteristics 
of kampong were including of high-density buildings and population with an incremental pattern of environmental growth. Kampong has a high ability to adapt the city development, so that, it can adjust to the future conditions efficiently (Silas, 1988). Residents of kampong, in generally, have a rural-urban cultural transformation. Cultures living in kampong can also be due to demands of an appropriate strategy in associate with various limitations. Limitations are able to give birth to the typical houses in Kampong's Surabaya. Folk architecture which gives birth to the typical ancient houses is formed from a transformation process that is gradually long and repetitive in accordance with local behaviour, habits and culture. An ancient house is a house which has age more than 50 years old and it has had sustainable until now. This is related to high adaptability of kampong residents to all forms and structures of living space (Wiryomartono, 1995). High adaptability is a potential to create a non-platonic form of residence. Relationships between residents and their houses are a relationship of interdependency transactional, which is humans' influence to house and vice versa are house influences to occupants (Bell, 2001). Folk architecture as part of vernacular architectures is an architecture which has closely related or contextual with local environment and resources that are processed and built with traditional technology (Oliver, 1997). This kind of architectures is an architecture that adapts local climate, uses local techniques and materials. The use of local techniques and material were influenced by social, cultural and economic aspects of local community.

The points of this study were all about bioclimatic adaptations that affect to the transformation of ancient house form and occupant behaviour in responding to the environment. The paradigm was used to discuss about interaction of architecture, environment and its occupant in this case was a sustainable aesthetic paradigm. Paradigm of sustainable aesthetics relates to an ongoing understanding of architectural aesthetic philosophy (Douglas, 2008), which there was a phenomenon of continuity and change.

\section{THEORY / RESEARCH METHODS}

Adaptation is a process which includes several main efforts in adjusts, reuse or upgrade an object (architectural) to make it more suitable for new conditions or needs, which is generally a direction as a number form of change. Adaptation in context of architecture can be divided into building adaptation and behavioural adaptation. Building adaptation takes the form of three principles, i.e. change of function, change in size and change in performance (Douglas, 2002). There are three concepts of building adaptation (Arge, 2005), i.e. generality, flexibility, and elasticity. While behavioural adaptations (Bell, 2001) are adaptation by reaction, adaptation by adjustment, adaptation by with a drawl. Climate can be a very important aspect that influence to a former of folk architecture as part of Vernacular Architecture (Rapoport, 1969). Adaptation patterns can be understood more comprehensively by using a bioclimatic approach that emphasizes to important of residential comfort, energy efficiency, and its contribution to a liveable city. 
Bioclimatic strategy would a designer direct to get interactive architectural design solutions to climate, biology and technology (Olgyay, 1963).

Building performance in bioclimatic context is determined by ability of building to provide comfort to residents and ensure efficient use of energy. The biggest challenge in realizing an environmental comfort is thermal comfort, followed by visual and psychological comfort. Meaning of thermal comfort based on a psychological approach is most complete (Jo, 2015). Meanwhile energy efficiency can be carried out in a cost of living cycle. This principle involves calculating building capital costs and building operational costs during of building life. Bioclimatic strategy is not focused on active systems but rather on passive systems through formations and building orientations that allow optimal design to reduce energy use.

This study is descriptive research that using field studies. A description method is to explain an interaction between building and its occupant that creates architecture of residential houses and its transformation. This descriptive study was deal with fact gathering, identifying and interpreting about relationships between variables. The variable observed were bioclimatic adaptation patterns, architectural configurations, occupant spatial interactions, comfort sensations and energy performance. Populations and samples for the objects in this study were ancient houses in Kampong Peneleh, Genteng Kali District, Surabaya. Kampong Peneleh is the oldest and authentic kampong of Surabaya with many historical memories, unique architecture and environment. Not only those the facts of kampong Peneleh, but also, this kampong is crowded and busy kampong since time immemorial, because of its strategic location. Data collection techniques were the instruments which used questionnaires, thermo-hygrometers data logger. Instruments analysis used bioclimatic chart for thermal performance evaluation. Meanwhile, calculation overall thermal transfer value (OTTV) as instrument analysis was to determine the energy performance. Finally, descriptive explanations were used to reveal the tendency of transformation in both buildings and its occupants.

\section{RESULTS AND DISCUSSION}

The finding of the present study showed few parts of important things. The first part was about adaptation pattern and level of bioclimatic adaptation. The second part was evaluation of thermal and energy performance. The third part was context of spatial interaction between building and its occupant. The last part was tendencies of transformations in building and its occupant.

\section{Adaptation Pattern}

Bioclimatic adaptation patterns were typical form of ancient houses in kampong which were influenced by architectural traditions and styles of Javanese, Colonial and Modern building. In Kampong Peneleh Surabaya, percentage of ancient houses existence consisted of 35\% Javanese House style, 18\% Colonial House style and 
47\% Modern House style. Each type of ancient house building has different levels of bioclimatic adaptation (Figure 1).

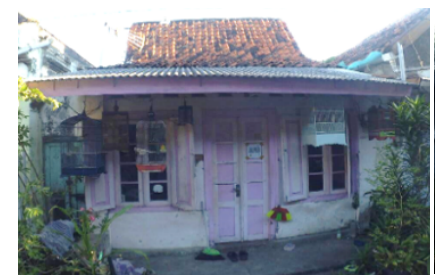

Colonial House style

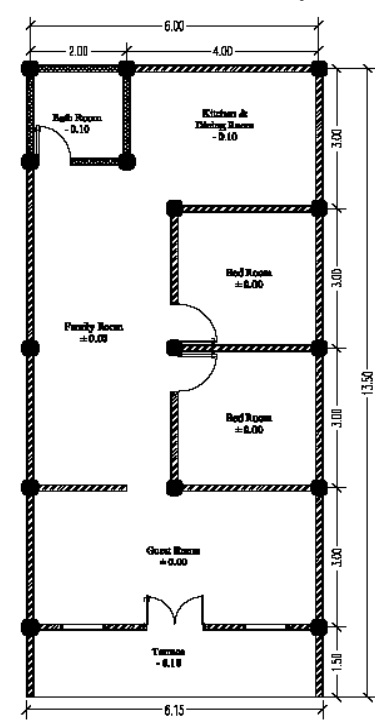

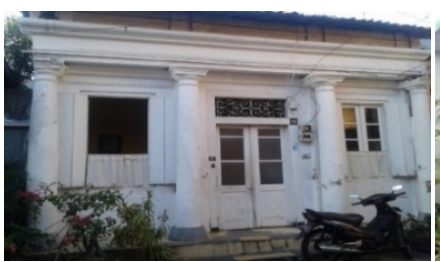

Modern House style

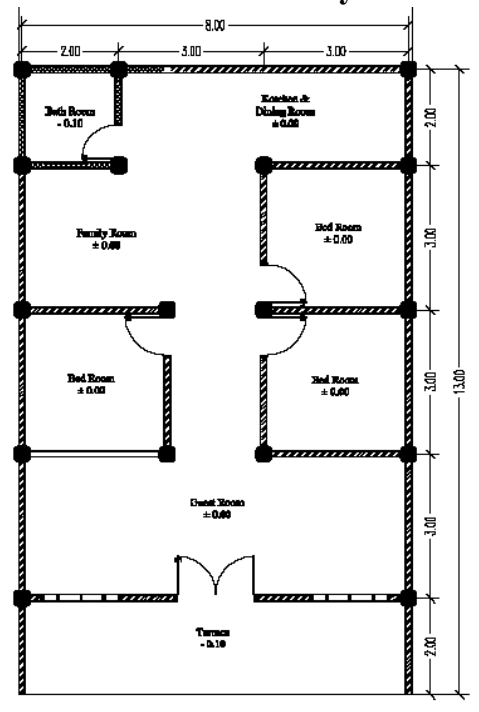

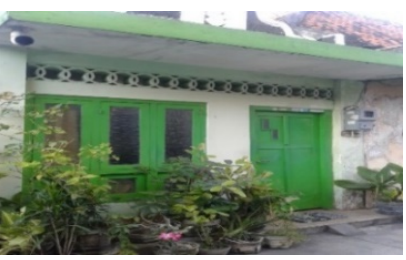

Colonial House

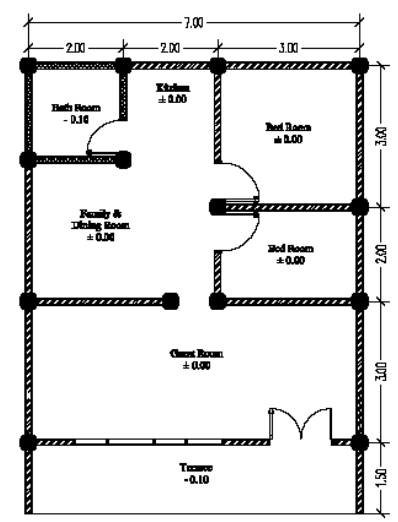

Figure 1. Typical of ancient house architecture in Kampong Peneleh Surabaya Source: Author, 2018

All types of ancient houses have had terraces as wide as the front side of building, which most extensive was a terrace in Colonial House while narrowest is in Modern House. The functions of front room in the house (from entrance) was as a Guest or Living room. For the next room, behind of Guest or Living room was Bedroom. In Colonial House, the placement of Bedroom that could be on the left and right side, in Javanese House and Modern House were mostly on a side only (usually right side), while another side was used as a Multipurpose room. Multipurpose room in this case could be used for Family room, Dining room, temporary Sleeping room and others. Semi-open Bathrooms/Toilets and Kitchens were placed in back of the house. In Colonial House, sometimes, the placement of Bathroom/Toilets, Kitchen and partly in kind of Maid Room were separated from the main house. Typology of ancient house plan in kampong looked similar between one house and another. 


\section{Thermal and Energy Performance}

Bioclimatic adaptation in addition was to affect the building configuration, human behavior and determines the thermal performance of buildings. Meanwhile the thermal conditions of various typical ancient houses in Kampong Peneleh Surabaya were shown in following graphic below (Figure 2).

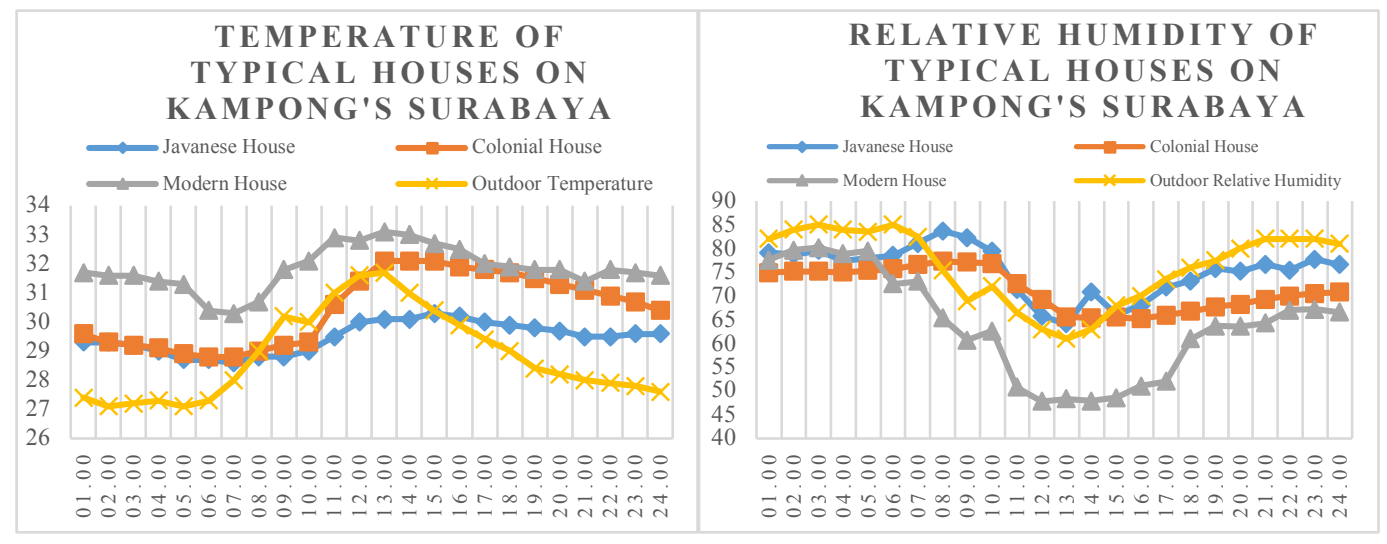

Figure 2. Thermal condition of typical ancient houses in Kampong Peneleh Surabaya Source: Personal Work, 2018

The architecture of Javanese Houses and Colonial Houses showed that thermal conditions were better than Modern Houses, which average temperature inside of Javanese House $\left(\mathrm{T}=29.5^{\circ} \mathrm{C}\right)$ and Colonial House $\left(\mathrm{T}=30.5^{\circ} \mathrm{C}\right)$ were lower than Modern Houses $\left(\mathrm{T}=31.8^{\circ} \mathrm{C}\right)$. Although the relative humidity average remained high in Javanese House ( $\mathrm{RH}=75.3 \%)$ and Colonial House $(\mathrm{RH}=71.4 \%)$ but it could create a more stable thermal condition than in Modern House $(\mathrm{RH}=63.8 \%)$. Appearance of Javanese House lookedto be simpler but thermally showedthe best performance. The use of building would envelope the materials with high porosity suchas wood wall and clay tiles as roof. Itallowed optimal respiration and evaporation. The configurations of wide openings werelike bovenlichsand windows both of them were reached $9-12 \%$ of facade area then alsopresence of a wide corridor in front of building which made indoor housebecame cooler. This Javanese House plan was not having a lot of solid wallpartitions in it (open floor plan), sothat air circulation was smoother. Whereas Colonial Houses tend to use more solid building envelope materials would be balanced with better ventilation such as wide windows and openings (ideally $20-40 \%$ of facade area) as right configuration, but in reality, it happened only $10-15 \%$ of facade area. Lately a lot of ventilations and windows were permanently closed which prevents air circulation within the room. The addition of solidwall partitionin interior building causes highhumidity within the room, especially if ventilations and windows were always closed, humidity would be difficult to reduce because air circulation was stagnant. Meanwhile in Modern Houses it seemed more concerned with appearance only than consideration 
of climate and environmental influences, so that thermal performance was the worst. Based on thermo-hygrometer data logger recording on multi purpose room could be seen as a tendency of thermal performance in extreme conditions that shown below (Table 1).

Table 1. Thermal condition of typical ancient housesin KampongPeneleh Surabaya

\begin{tabular}{lcccc}
\hline \multirow{2}{*}{ Performance } & \multicolumn{2}{c}{ Early day } & \multicolumn{2}{c}{ Afternoon } \\
& $\left({ }^{\circ} \mathrm{T}\right)$ & $(\% \mathrm{RH})$ & $\left({ }^{\circ} \mathrm{T}\right)$ & $(\% \mathrm{RH})$ \\
\hline Javanese House & 27,4 & 84,3 & 32,5 & 63,2 \\
Colonial House & 28,8 & 75,7 & 35,6 & 43,6 \\
Modern House & 29,0 & 80,5 & 34,9 & 44,8 \\
\hline
\end{tabular}

Source: Personal Work, 2018

Based on the building thermal conditions, tendency of thermal comfort could be evaluated by bioclimatic chart. The thermal comfort of typical ancient houses in Kampong Peneleh Surabaya could be seen on following bio climatic chart below (Figure 3).

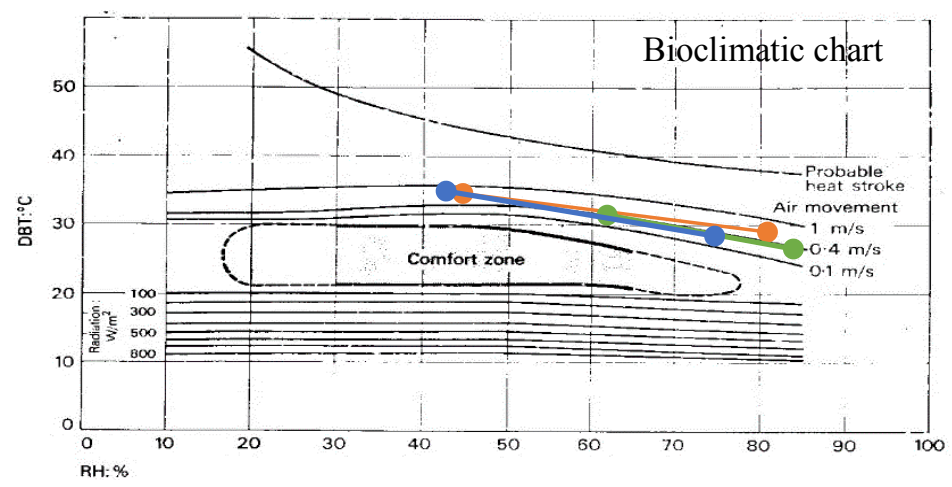

Figure 3. Thermal performance of typical ancient houses at Kampong Peneleh Surabaya

Source: Personal Work, 2018

In general, thermal conditions inside the building were better than outside of the building, but it has not been able to improve the thermal comfort for occupant which caused in all of typical houses were the air flow too low. The air flow was only $0.1 \mathrm{~m} / \mathrm{sec}$ or even less than. Thermal comfort would be achieved if there was an air flow of $0.2-1.0 \mathrm{~m} / \mathrm{sec}$.

The most used of electrical energy in residential houses was cooling load of the room, which reaches $38-40 \%$ of overall electrical energy (Prianto, 2007). Cooling load was greatly influenced by solar heat infiltration in addition to heat gain coming from inside building itself. Amount of heat infiltration into building could 
be traced from overall thermal transfer value (OTTV) of the building envelope which exposed to the solar heat. In kampong with high density buildings, the facade configuration has had a function as a building envelope which has had the most significant influence on difference of OTTV. While the roof as a building envelope has had almost the same effect because area and type of roof cover were as same as by using clay tiles. The totally of OTTV was sum of OTTV which infiltration through the exposed walls and RTTV infiltration over the roof (Table 2).

Table 2. Overall Transfer Thermal Value (OTTV) typical ancient house at Kampong Peneleh Surabaya

\begin{tabular}{|c|c|c|c|c|c|c|c|}
\hline \multirow[b]{2}{*}{ No. } & \multirow{2}{*}{$\begin{array}{c}\text { Style and } \\
\text { House Positions }\end{array}$} & \multicolumn{4}{|c|}{ OTTV W/m² } & \multirow{2}{*}{$\begin{array}{l}\text { RTTV } \\
\mathrm{W} / \mathrm{m}^{2}\end{array}$} & \multirow{2}{*}{$\begin{array}{l}\text { Totally } \\
\text { OTTV } \\
\text { W/m² }\end{array}$} \\
\hline & & Front & Back & Corner & Average & & \\
\hline A & $\begin{array}{l}\text { Javanese House } \\
\text { Facing South }\end{array}$ & & & & & & \\
\hline 1 & $\overline{\text { Corner house }}$ & 21,36 & 20,58 & 26,49 & 22,81 & 44,76 & 67,57 \\
\hline 2 & $\begin{array}{l}\text { Middle house } \\
\text { Facing North }\end{array}$ & 21,36 & 20,58 & - & 20,97 & 44,76 & 65,73 \\
\hline 1 & $\overline{\text { Corner house }}$ & 22,03 & 20,18 & 26,49 & 22,90 & 44,76 & 67,66 \\
\hline 2 & Middle house & 22,03 & 20,18 & - & 21,11 & 44,76 & 65,87 \\
\hline $\mathrm{B}$ & $\begin{array}{l}\text { Colonial House } \\
\text { Facing South }\end{array}$ & & & & & & \\
\hline 1 & $\overline{\text { Corner house }}$ & 24,49 & 24,30 & 26,49 & 25,10 & 44,76 & 69,86 \\
\hline 2 & $\begin{array}{l}\text { Middle house } \\
\text { Facing North }\end{array}$ & 24,49 & 24,30 & - & 24,41 & 44,76 & 69,17 \\
\hline 1 & $\overline{\text { Corner house }}$ & 25,01 & 23,94 & 26,49 & 25,15 & 44,76 & 70,02 \\
\hline 2 & Middle house & 25,01 & 23,94 & - & 24,48 & 44,76 & 69,91 \\
\hline $\mathrm{C}$ & $\begin{array}{l}\text { Modern House } \\
\text { Facing South }\end{array}$ & & & & & & \\
\hline 1 & $\overline{\text { Corner house }}$ & 23,62 & 22,56 & 26,49 & 24,23 & 44,76 & 68,99 \\
\hline 2 & $\begin{array}{l}\text { Middle house } \\
\text { Facing North }\end{array}$ & 23,62 & 22,56 & - & 23,09 & 44,76 & 67,85 \\
\hline 1 & $\overline{\text { Corner house }}$ & 24,16 & 21,14 & 26,49 & 23,93 & 44,76 & 68,69 \\
\hline 2 & Middle house & 24,16 & 21,14 & - & 22,65 & 44,76 & 67,41 \\
\hline
\end{tabular}

OTTV calculation showed that Javanese House with a wide overhang compared to low building heightand making facade was making much overshadow from exposure to the solar heat. So that, overall thermal transfer value (OTTV) could be reduced. OTTV Javanese House 66-68 W/m2, Colonial House 69-70 W/m2, Modern House 67-69 W/m2. Colonial House building height was supported by a large attic volume but the building without roof ventilation remained a good heat insulation, which reduced heat infiltration into the room. Building direction relative to the solar heat exposure was also playing a role in reducing an amount of heat that strikes building. However, totally OTTV size was still higher than energy saving building which electricity consumption which was only $45 \mathrm{~W} / \mathrm{m} 2$ (Indonesian National Standart). However, the passive system mechanisms to optimize natural ventilation and lighting in ancient houses must be supported by using fan equipment 
for cooling the room, enabling the efficiency of electrical energy. The building which was very friendly to the climate and environmentally responsive could save electrical energy up to $60-70 \%$ and would save up to $30-40 \%$ more if it involves elements of vegetation and water (Prianto, 2007). Very limited park or outdoor space in Kampong Peneleh Surabaya were caused by a role of vegetation and water to be almost no effect. Based on the questionnaire could be known the average of monthly electricity cost (basic electricity tariff 1467.28 IDR per kWh) on Javanese House 380,000 IDR equivalent with $259 \mathrm{kWh}$, in Colonial House 400,000 IDR equivalent with $273 \mathrm{kWh}$, in Modern House 440,000 IDR equivalent with $300 \mathrm{kWh}$. OTTV values have had an impact to the electrical energy consumption of typical ancient houses are shown in the following diagram (Figure 4).

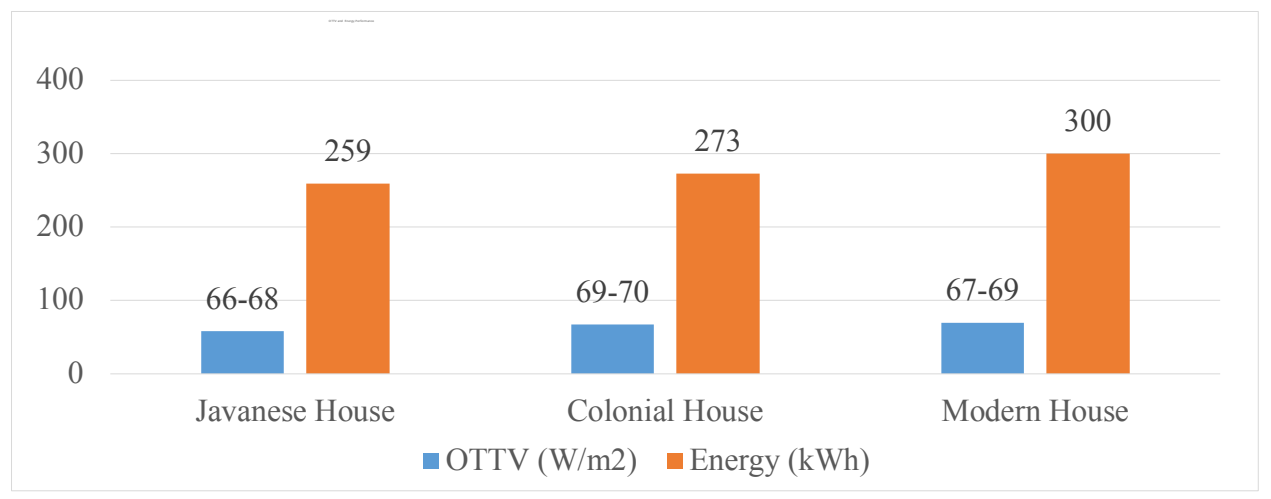

Figure 4. Profile of overall thermal transfer value and electricity load per month of typical ancient houses in Kampong's Peneleh Surabaya

Source: Personal Work, 2018

Environmental comfort included physical, psychological and physiological comfort. Physical comfort was influenced by thermal conditions in building. Psychological comfort is related to safety, quiet environmental conditions and good social interaction. Physiological comfort was related to make easier the accessing of utility services for needs and wants of everyday life. Based on the questionnaire, it could be concluded that environmental comfort in generalwas not too bad even though an occupancy satisfaction indexclose to $50 \%$. Thermal comfort could naturally be felt around 4:00-8:00 a.m. in the morning.

\section{Transformations}

The behavior of residents in responding the climate and environmental conditions was very significant in creating to environment comfortable and energy efficient. Active behavior was needed in realizing a thermal comfort by passive building system technique. Behavioral adaptation of residents was createdby daily habits such as opening all windows in the morning around 6:00 a.m. and closing it again in the afternoon around 5:00 p.m. The habit of turn fans off during 1:00 until 3:00 p.m. and turn onthe fan at the evening around 6:00-9:00 p.m. Napping habits usually 
carry out around 1:00 a.m. to 3:00 p.m. when an ambient temperature reached hottest peak conditions. However, lately, many occupant's behavior has led to decrease level of bioclimatic adaptation. The tendency closing windows and bovenlichts were the reasons to reduce dust, pollution or safe the fresh air which flowed into the room to stagnate. So, that temperature and humidity were also increasing. These unfavorables were changing the results in decrease the thermal and energy performance.

Changing in a physical form of house buildings was not more than $30 \%$ while changing in the environment was around $10 \%$ in the effort of tidy up the environment and make greening by planting flowers in pots, but it was not really significant. Physical changes to the building were simplification of the plan by reducing solid partitions and changing the interior or exterior colors. The new materials were like more solid walls and roofs with large transmittance (U-value), it made the room hotter and cooling load of the room was increasing. The other aspects like social, economic, and culture conditions still remain relatively stable and even tend to stagnant because of many old residents were over 50 years old which still stayed there.

\section{CONCLUSIONS}

Bioclimatic adaptation of ancient houses in Kampong Peneleh Surabaya formed typical Javanese House style, Colonial House style and Modern House style with different levels of bioclimatic adaptation performances. Bioclimatic adaptation allowedbuildings'transformation and occupant's behavior to be more responsive to the climate and environment. Typically, level of adaptation of Javanese Houses and Colonial Houses was better than Modern Houses. This was indicated by relatively good thermal conditions in ancient houses which those buildings were still original.

Physical changes to the building and environmentwere not really significant because they were only a simplification of the plan by reducing permanent partitions and changes interior or exterior colors. However, the habits of opening windows and doors or turning on air conditioning equipment at certain times have begun to become disorganize because it was considered impractical. Therefore, the spatial interaction between buildings and occupants has decreased. This has an impact on increasing the building's operational costs to get a thermal comfortwhich was decreasing.

Social, economic, and environmental changedwere not very significant because there were more elderly people that stayed there. The residents also began to careless to the environment because they were busy for working outside, thus the kampong tended to be quiet from outdoor activities of the house.

Actually, comfort of houseenvironment could be pursued through active interaction between building houses and their occupants with a passive building system mechanism to save energy. A balance transactional interdependency between building and occupants would affect to performance of both thermal comfort and energy efficient. 


\section{REFERENCES}

Arge, S. I., et al. (2005), Viking and Medieval Settlement in the Faroes: People, Place and Environment, Human Ecology: An Interdisciplinary Journal 33 (5).

Bell, P. A., Greene, T. C., Fisher, J. D. \& Baum, A. (2001), Environmental Psychology. Fifth ed., Wadsworth Group, Belmont, California USA.

Douglass, David B. (2008), Defining A Sustainable Aesthetic: A New Paradigm for Architecture, A Thesis Master of Building Science.Faculty of The School of Architecture University of Southern California, USA.

Douglas, James (2002), Building Adaptation. Butterworth-Heinemann, Edinburgh U. K.

Jo, Mu-Jin, et al. (2015), Evaluation System for Psychological Comfort towards Korean Traditional Residence International Conference on Advances in Agricultural, Biological \& Environmental Sciences.AABES-2015, London U. $\mathrm{K}$.

Olgyay, Victor (1963), Design with Climate - Bioclimatic Approach to Architectural Regionalism. Van Nostrand Reinhold, New York.

Oliver, Paul (1997), Encyclopedia of vernacular architecture of the world: Theories and principles. Volume 1, Cambridge University Press, New York, USA.

Prianto, E. (2007), Rumah Tropis Hemat Energi Bentuk Kepedulian Global Warming, Jurnal Riptek. Vol. 1 No. 1, November 2007.

Rapoport, A. (1969), House Form and Culture - Foundations of Cultural Geography Series. Prentice-Hall Inc., Englewood Cliff, New York USA.

Silas, Johan (1988), TheKampongs of Surabaya. Municipal Government of Surabaya. Wiryomartono, Bagoes P. (1995), Seni Bangunan dan Seni Binakota di Indonesia. PT. Gramedia Utama Pustaka, Jakarta. 